\title{
Hoplolabis (Parilisia) staryi sp.n., a new species of Limoniidae (Diptera) from East Kazakhstan
}

\section{Hoplolabis (Parilisia) staryi sp.n. - новый вид комаров Limoniidae (Diptera) из Восточного Казахстана}

\author{
V.I. Devyatkov \\ В.И. Аевятков
}

Kazakh Institute of Fish Research, Altai Branch, Protozanova str. 83, Ust-Kamenogorsk 070004 Kazakhstan. E-mail: devyatkovvi@inbox.ru.

Алтайский филиал Казахского НИИ рыбного хозяйства, ул. Протозанова 83, Усть-Каменогорск 070004 Казахстан.

Key words: Diptera, Limoniidae, Hoplolabis, new species, Palaearctic Region, Kazakhstan.

Ключевые слова: Diptera, Limoniidae, Hoplolabis, новый вид, Палеарктика, Казахстан.

Abstract. Hoplolabis (Parilisia) staryi sp.n., a new species of short-palped crane flies, is described and illustrated based on the male and female adults from East Kazakhstan (southern Altai Mts). The new species is compared with related species of the subgenus Parilisia Savchenko, 1976. Two species, Hoplolabis (Parilisia) serratofalcata (Savchenko, 1983) and Hoplolabis (Parilisia) yezoana (Alexander, 1924), are reported as new to the fauna of Kazakhstan.

Резюме. Приведено иллюстрированное описание нового вида комаров-лимониид Hoplolabis (Parilisia) staryi sp.n. из Восточного Казахстана (Южный Алтай) по имаго самца и самки. Новый вид сравнивается с близкородственными видами подрода Parilisia Savchenko, 1976 Выявлено два новых для фауны Казахстана вида Hoplolabis (Parilisia) serratofalcata (Savchenko, 1983) и Hoplolabis (Parilisia) yezoana (Alexander, 1924).

The genus Hoplolabis Osten Sacken, 1869 includes 41 species from 3 subgenera; the largest subgenus Parilisia includes 31 Palaearctic species [Oosterbroek, 2018]. Five species of Hoplolabis (Parilisia) are known from Kazakhstan [Savchenko, 1978, 1983]. In 2017, males and females of an unknown species of Hoplolabis (Parilisia) were collected during a research of mountain streams near the high-altitude lakes of the southern Altai Mts, East Kazakhstan.

This study provides the description and figures of the adult male and female of Hoplolabis (Parilisia) staryi sp.n. Two other species of Parilisia are here recorded from Kazakhstan for the first time.

The holotype and some paratypes will be transferred to the Institute of Systematics and Ecology of Animals, Novosibirsk, Russia (ISEA). Other paratypes are deposited in the Altai Branch of the Kazakh Institute of Fish Research, Ust-Kamenogorsk, Kazakhstan.

Specimens were collected by sweeping and preserved in $70 \%$ ethanol, each specimen with its prepared genitalia. Specimens were studied with a MBS-10 microscope. Male genitalia were boiled in $10 \%$ solution of potassium hydroxide $(\mathrm{KOH})$ for 180 s and washed in distilled water. Free hand drawings of the processed and dissected male genitalia, as well as those of a separated male wing and female ovipositor are illustrated using an ocular micrometer. Terminology of morphological features generally follows that of E.N. Savchenko [Savchenko, 1986].

\section{Hoplolabis (Parilisia) staryi Devyatkov, sp.n. Figs $1,3-8$}

Material. Holotype: $\sigma^{x}$ - Kazakhstan: Katon-Karagai State National Nature Park, Belaya River from Maral'e Lake $\left(49^{\circ} 25^{\prime} 18^{\prime \prime} \mathrm{N} ; 85^{\circ} 58^{\prime} 42^{\prime \prime} \mathrm{E}\right), 1770 \mathrm{~m}$ a.s.l., 20.VI.2017, leg. V.I. Devyatkov. Paratypes: $20^{7} 0^{7}$, 5 우우, same data as holotype $2 \sigma^{7} \sigma^{7}$, Markakol State Nature Reserve, small stream to Markakol Lake $\left(48^{\circ} 46^{\prime} 21 " \mathrm{~N} ; 86^{\circ} 0^{\prime} 0 " \mathrm{E}\right), 1470 \mathrm{~m}$ a.s.l., 2.VII.2017; all leg. V.I. Devyatkov.
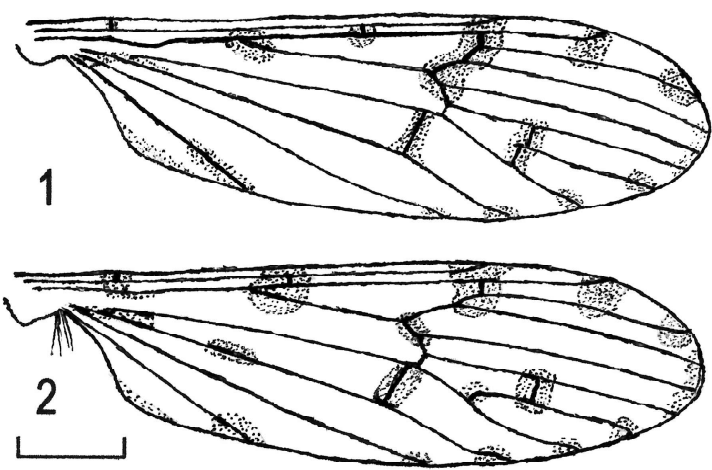

Figs 1-2. Male wing: 1 - Hoplolabis (Parilisia) staryi sp.n.; 2 - Hoplolabis (Parilisia) serratofalcata (Savchenko, 1983). Scale bar $1 \mathrm{~mm}$

Рис. 1-2. Крыно самца: 1 - Hoplolabis (Parilisia) staryi sp.n.; 2 - Hoplolabis (Parilisia) serratofalcata (Savchenko, 1983). Масштабная минейка 1 мм. 


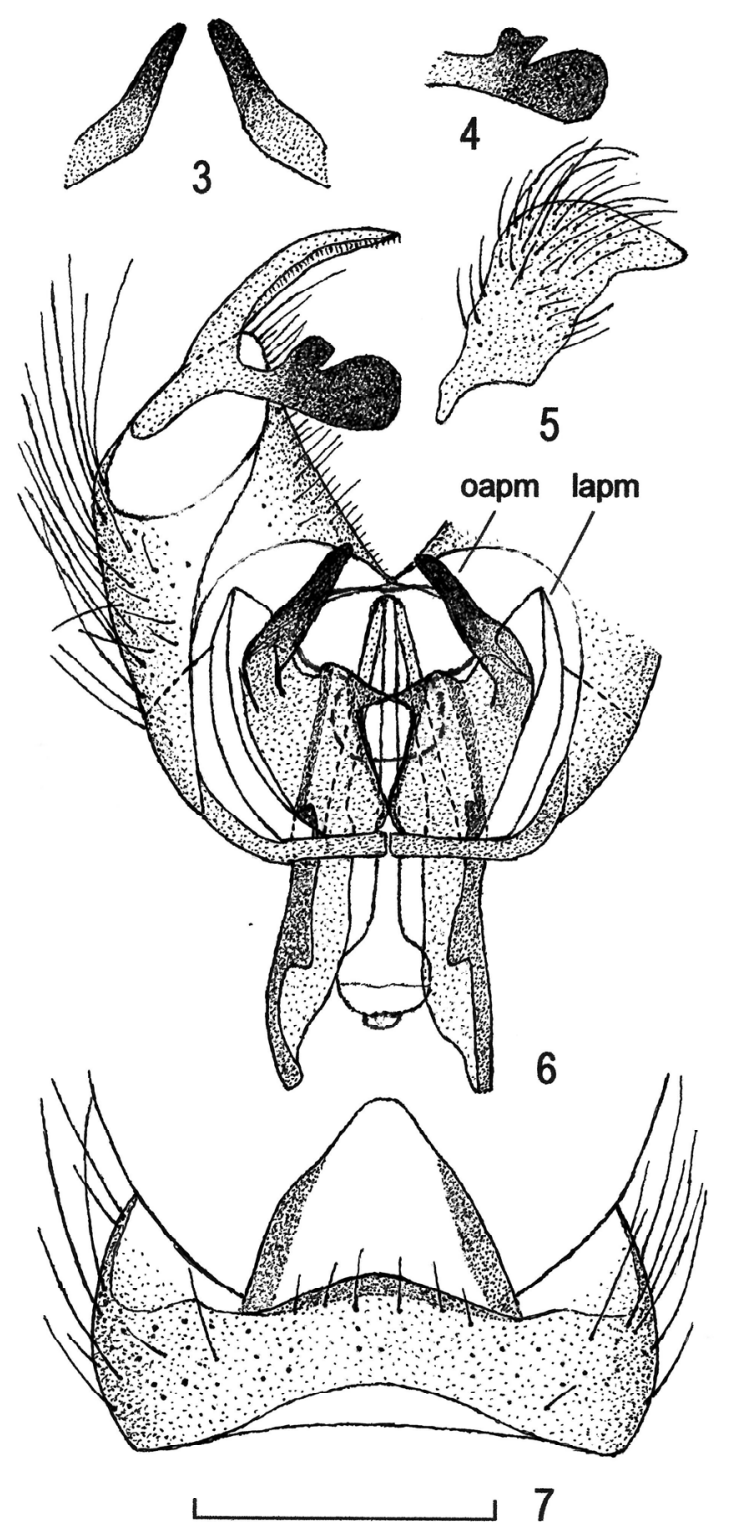

Figs 3-7. Hoplolabis (Parilisia) staryi sp.n.: 3 - outer arms of parameres (before hot treatment in $\mathrm{KOH}$ solution), ventral view; 4 - inner and intermediate arms of ventral gonostylus, ventral view; $5-$ dorsal gonostylus, ventrolateral view; $6-$ male hypopygium (tergite IX and dorsal gonostylus not shown), ventral view; 7 - tergite IX with proctiger, ventral view. Abbreviations: oapm - outer arm of paramere, lapm - lateral arm of paramere. Scale bar $0.3 \mathrm{~mm}$.

Pис. 3-7. Hoplolabis (Parilisia) staryi sp.n.: 3 - внешние ветви парамеров (Ао термической обработки в растворе

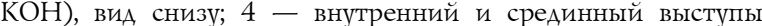
вентрального гоностиля, виА снизу; 5 - Аорзальный гоностиль, нижнебоковой виА; 6 - гипопигий самца (тергит IX и дорзальный гоностиль не показаны), виА снизу; 7 - тергит IX с проктигером, виА снизу. Сокрашения: оарт - внешняя ветвь парамеров, lapm - боковая ветвь парамеров. Масштабная минейка 0,3 мм.
Description. Male (Figs 1, 3-7). General coloration brown to dark brown. Body length 5.0-6.0 mm, wing length 6.6$7.3 \mathrm{~mm}$.

Head dark brown to blackish brown. Rostrum and palpus brown or dark brown. Antenna of moderate length, if bent backward reaching to base of wing or extending slightly beyond it. Scape brown; pedicel light brown, rarely yellowish; proximal flagellar segments light brown (1st segment lightest), distal segments brown. Scape almost rectangular, slightly longer than wide; pedicel approximately rounded, from base to apex slightly widened; flagellar segments elongated-oval, about equal in length, proximal segments 2.02.5 times wider than distal ones. Proximal and distal flagellomeres with verticils shorter than respective segments, median ones with verticils slightly longer than segments. Short dense pubescence observable on all flagellomeres.

Thorax. Pronotum brown, dark brown along anterior margin. Prescutum light brown, with 4 brown to dark brown longitudinal stripes; inner stripes separated by narrow light line, sometimes almost invisible. Scutal lobes dark brown, with yellowish posterolateral areas; scutellum brownish; postscutellum and pleuron brown to dark brown.

Legs generally yellowish to brownish yellow, femora in distal third or fourth dark brown, tibiae at base and apex brown to dark brown; tarsal segments brown to dark brown, 1st segment in proximal part sometimes brownish yellow.

Wing (Fig. 1) slightly tinged light brownish, pattern consisting of five small brown spots near anterior margin: at origin of $r s$, on $s c_{2}, s c_{1}-r q, r_{1}$ and $r_{2}$; light brown marginal spots at ends of veins $m_{3}, m_{4}, c u$ and $a_{2}$; smoky spots at ends of veins $r_{3}, r_{4+5}, m_{1+2}, a_{1}$ and along anal angle; brown spots on all transversal veins, except $h$ and base of $D$ (1st section of $\left.m_{l+2}\right)$. Veins mostly yellowish, brown within markings. Venation: $s c_{2}$ ending opposite or slightly beyond half-length of long $r s, m-c u$ opposite or shortly before fork of $m$. Cell $D$ relatively short, 2nd section of $m_{1+2}$ (upper margin of cell $D$ ) about $45-65 \%$ of length of 3 rd section of this vein, however $m_{3+4}$ relatively long, about $90-120 \%$ of length of $m_{4}$; apex of $D$ about 4 times wider than its base. Halter with knob whitish.

Abdomen generally brown to dark brown; segment VIII brownish yellow to brown, strongly reduced; sternite I in proximal half yellowish; sternite II with yellowish anterolateral areas, medially with dark brown triangular spot, its point directed forward.

Hypopygium (Fig. 6, tergite IX and dorsal gonostylus shown in Figs 7 and 5, respectively) brownish yellow, twisted $180^{\circ}$. Tergite and sternite IX merged into entire genital ring. Tergite IX (Fig. 7) transverse, medially not divided; its posterior margin with wide but short rounded median projection, darkly pigmented posteriorly. Proctiger large, laterally pigmented, its apex triangularly narrowed. Gonocoxite short, only slightly longer than its width, with long setae along outer margin and shorter ones along inner margin. Ventral gonostylus with 1 short and 2 long arms. Outer arm long and moderately broad, 3-4 times longer than its maximal width (in middle part), slightly curved and subacute at tip; yellow to brownish yellow, slightly sclerotized; its inner surface with numerous very short hairs. Inner arm long, clavate (club-shaped), with broadly rounded apex; brownish yellow at base, then intensely dark brown pigmented. Intermediate arm as small darkened square or rectangular plate (see Fig. 6), sometimes with pointed inner corner (Fig. 4), located on inner side of inner arm as lateral outgrowth of the latter. Dorsal gonostylus (Fig. 5) fleshy, directed upwards and 
inwards, relatively broad, moderately long, a little expanding from base, in distal fourth curved mesally to subacute tip; with numerous rather long setae.

Outer arm of paramere (Fig. 3) as long flat rod, gradually tapering to narrowly rounded apex, in proximal third curved back and inward, in distal half or third intensely pigmented, blackened. Inner arm of paramere reduced. Bases of outer arms with large sclerotized plates mesally, connecting with each other medially in front and rear. Outer arm of paramere laterally with curved plate to be called lateral arm of paramere. This plate weakly sclerotized, with rounded apex and inward folded tergal edge.

Female resembling male in general appearance. Body length with ovipositor $6.3-7.3 \mathrm{~mm}$, wing length $7.2-8.6 \mathrm{~mm}$. Antenna shorter than in male, if bent backward not reaching to base of wing; scape dark brown, rarely brown; pedicel from yellowish to brown; flagellum brown, 1st segment sometimes light brown. Female ovipositor (Fig. 8) elongated and slender, yellow to brownish yellow; tergite $\mathrm{X}$ dark brown in proximal part, sternite IX medially yellowish brown; thin cerci evenly curved, with pointed tips; valves protruding noticeably beyond middle of cerci.

Etymology. The new species is named in honour of the outstanding dipterologist Jaroslav Stary, who made a considerable contribution to the knowledge of Palaearctic Tipuloidea.

Diagnosis and comparison with related species. The new species belongs to the group of Middle Asian species of the subgenus Parilisia with patterned wings and weakly sclerotized lateral outgrowths of the parameres [Savchenko, 1983]. Of this group, $H$. (P.) staryi is closest to $H$. $(P$. serratofalcata (Savchenko, 1983) and $H$. (P.) obtusirama (Savchenko, 1983), whose wings lack dark seams or spots on longitudinal veins except at midlength of $c u$. The new species

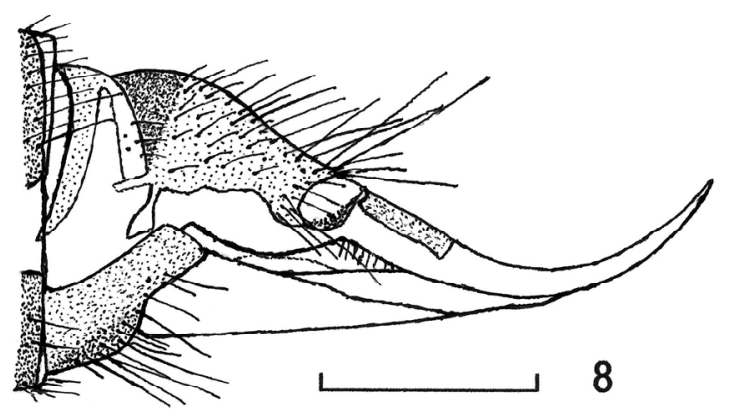

Fig. 8. Hoplolabis (Parilisia) staryi sp.n.: ovipositor, lateral view. Scale bar $0.5 \mathrm{~mm}$

Рис. 8. Hoplolabis (Parilisia) staryi sp.n.: яйцекмаА, виА сбоку. Масштабная минейка 0,5 мм.

differs significantly from $H$. (P.) serratofalcata and $H$. (P.) obtusirama by atrophy of the inner arm of the paramere, and by other details of the structure of hypopygium, wing pattern and peculiarities of venation (Table 1).

Besides, in the new species vein $m_{3+4}$ is relatively long, about $90-120 \%$ of the length of $m_{4}$ (Fig. 1), whereas in $H$. (P.) serratofalcata vein $m_{3+4}$ is short, about $43-48 \%$ of the length of $m_{4}$ (Fig. 2).

A female of Hoplolabis (Parilisia) badakhensis (Alexander, 1955) with patterned wings was described from Afghanistan [Alexander, 1955]. The female of $H$. (P.) staryi is distinguished from the female of $H$. ( $P$.) badakhensis by details of the coloration of the wings, some parts of the body, and peculiarities of venation (Table 2).

Table 1. The main morphological distinctions between H. (P.) obtusirama, H. (P.) serratofalcata and H. (P.) staryi sp.n. males Таблица 1. Основные морфологические различия между самцами Н. (P.) obtusirama, H. (P.) serratofalcata и H. (P.) staryi sp.n.

\begin{tabular}{|l|l|}
\hline \multicolumn{1}{|c|}{$\begin{array}{l}\text { H. (P.) obtusirama (Savchenko, 1983) } \\
\text { H. (P.) serratofalcata (Savchenko, 1983) }\end{array}$} & \multicolumn{1}{|c|}{ H. (P.) staryi sp.n. } \\
\hline Vein $c u$ with dark longitudinal spot at midlength & Vein $c u$ without dark longitudinal spot at midlength \\
\hline Vein $s_{2}$ opposite from one-fourth to one-third length of $r s$ & Vein $s c_{2}$ opposite middle of $r s$ \\
\hline $\begin{array}{l}\text { Tergite IX divided medially into two oblique, mesally strongly } \\
\text { narrowed, approximately triangular parts }\end{array}$ & $\begin{array}{l}\text { Tergite IX not divided medially; its posterior margin with wide, low, } \\
\text { rounded median elevation, darkly pigmented posteriorly }\end{array}$ \\
\hline $\begin{array}{l}\text { Intermediate arm of ventral gonostylus as straight or hook-shaped } \\
\text { spine between outer and inner arms of ventral gonostylus }\end{array}$ & $\begin{array}{l}\text { Intermediate arm of ventral gonostylus as small, approximately } \\
\text { square plate on inner side of inner arm }\end{array}$ \\
\hline Dorsal gonostylus long, relatively narrow, with rounded apex & $\begin{array}{l}\text { Dorsal gonostylus moderately long, relatively broad, in distal fourth } \\
\text { curved mesally to subacute tip }\end{array}$ \\
\hline $\begin{array}{l}\text { Outer arm of paramere as massive crescent-shaped rod, serrate at } \\
\text { outer margin, entirely intensely pigmented }(H . \text { serratofalcata), or as } \\
\text { curved, pigmented, smooth strip slightly widened distally } \\
\text { (H. obtusirama) }\end{array}$ & $\begin{array}{l}\text { Outer arm of paramere as curved flat rod, gradually tapering to } \\
\text { narrowly rounded apex, darkly pigmented in distal half or third }\end{array}$ \\
\hline $\begin{array}{l}\text { Inner arm of paramere hook-shaped, curved inwards, intensely } \\
\text { pigmented }\end{array}$ & Inner arm of paramere atrophied \\
\hline
\end{tabular}

Table 2. The main morphological distinctions between H. (P.) badakhensis and H. (P.) staryi sp.n. females Таблица 2. Основные морфологические разцичия между самками Н. (Р.) badakhensis и Н. (P.) staryi sp.n.

\begin{tabular}{|c|c|}
\hline H. (P.) badakhensis (Alexander, 1955) & H. (P.) staryi sp.n. \\
\hline Tibiae yellowish white, tips narrowly darkened & $\begin{array}{l}\text { Tibiae yellow to brownish yellow, brown or dark brown at base and } \\
\text { apex }\end{array}$ \\
\hline Halter whitened, apex of knob dark brown & Halter and knob whitish \\
\hline Veins $m, m_{4}$ and $a_{1}$ with dark spots at midlength & Veins $m, m_{4}$ and $a_{1}$ without dark spots at midlength \\
\hline Vein $s c_{2}$ far retracted, just beyond origin of $r s$ & Vein $s c_{2}$ opposite middle of $r s$ \\
\hline $\begin{array}{l}\text { Length of } 2 \text { nd section of } m_{1+2} \text { about } 66-100 \% \text { of length of 3rd section } \\
\text { of } m_{1+2}\end{array}$ & $\begin{array}{l}\text { Cell } D \text { relatively short, length of } 2 \text { nd section of } m_{1+2} \text { about } 45-65 \% \text { of } \\
\text { length of } 3 \text { rd section of } m_{1+2}\end{array}$ \\
\hline
\end{tabular}


Диагноз. Новый вид относится к группе среднеазиатских видов подрода Parilisia, характеризующихся пятнистыми крыльями и наличием слабо склеротизированных боковых выростов парамеров [Savchenko, 1983]. Из этой группь $H$. (P.) staryi наиболее близок к видам $H$. (P.) serratofalcata (Savchenko, 1983) и H. (P.) obtusirama (Savchenko, 1983), у которых на крыльях отсутствуют тёмные штрихи или пятна на продольных жилках, за исключением средней части жилки $c u$. Новый вид существенно отличается от $H$. (P.) serratofalcata и $H$. (P.) obtusirama редукцией внутренних ветвей парамеров, другими деталями строения гипопигия, окраски крыльев и особенностями жилкования (табл. 1). Кроме приведённых в таблице отличительных признаков, у нового вида жилка $m_{3+4}$ относительно длинная, составляет 90-120\% длины $m_{4}$ (рис. 1), в то время как у $H$. $\left(P\right.$.) serratofalcata жилка $m_{3+4}$ короткая, составляет 43-48 \% длины $m_{4}$ (рис. 2).

Из Афганистана по самке описан вид Hoplolabis (Parilisia) badakhensis (Alexander, 1955) с пятнистыми крыльями [Alexander, 1955]. Самка H. (P.) staryi sp.n. отличается от самки $H$. (P.) badakhensis деталями окраски крыльев, некоторых частей тела и особенностями жилкования (табл. 2).

Variability. In one male from the vicinity of Markakol Lake, tergite IX is medially divided by a barely noticeable longitudinal line, with a longer median projection of the posterior margin and with a very shallow $\mathrm{V}$-shaped notch at the apex. The second male from the same locality, teneral and very pale, with the hypopygium not inverted.

Habitat. The new species was collected near streams among herbaceous vegetation, shrubs and trees on the shore of mountain lakes, $1470-1770$ m a.s.l.

\section{First ReCORdS OF Hoplolabis (PARILISIA) IN KAZAKHSTAN}

Hoplolabis (Parilisia) serratofalcata (Savchenko, 1983)

Material. Kazakhstan: $60^{7} \sigma^{7}$, 599 , about $25 \mathrm{~km}$ east from Ridder, Poperechnaya River (5021'22" N; 8353'31" E), 1170 m a.s.l., 29-30.VI.2014, leg. V.I. Devyatkov.

\section{Hoplolabis (Parilisia) yezoana}

(Alexander, 1924)

Material. Kazakhstan: $10^{\prime}, 1$, , Ust-Kamenogorsk, Ulba River $\left(49^{\circ} 58^{\prime} 55^{\prime \prime} \mathrm{N}\right.$; 8240'21" E), $300 \mathrm{~m}$ a.s.l., 24.VII.2013; $10^{7}$, same locality, 21.VI.2014; $20^{7} \sigma^{7}$, 2o+ , same locality, 810.VIII.2015; $10^{7}$, same locality, 29.VIII.2015; $10^{7}$, 2o+o, same locality, 30.VIII.2016; 10", 19, $30 \mathrm{~km}$ south from UstKamenogorsk, Urunkhai River $\left(49^{\circ} 40^{\prime} 25^{\prime \prime} \mathrm{N} ; 82^{\circ} 39^{\prime} 21^{\prime \prime} \mathrm{E}\right)$, 463 m a.s.l., 10.VI.2017; 10", village Chernovoe, KatonKaragai SNNP, Chernovaya River (49 $13^{\prime} 38^{\prime \prime}$ N; 85 53'09" E), 880 m a.s.l., 3.VIII.2017; all leg. V.I. Devyatkov.

\section{Acknowledgement}

I am very grateful to Dr Jaroslav Stary, Olomouc, Czech Republic, for his kind support, improving the manuscript and correcting the English text.

\section{References}

Alexander C.P. 1955. New or little-known Tipulidae (Diptera). XCVIII. Oriental-Australasian species // Annals and Magazine of Natural History. Ser.12. Vol.7. P.895-912.

Oosterbroek P. 2018. Catalogue of the Craneflies of the World. Online version at http://ccw.naturalis.nl. Last update: 13 February 2018.

Savchenko E.N. 1978. Additions to the fauna of the Limoniidflies (Diptera, Limoniidae) of the Northern Tien Shan // Vestnik Zoologii. No.5. P.40-49. [In Russian, with English summary].

Savchenko E.N. 1983. The Limoniid-flies (Diptera, Limoniidae) of the Ilisia (Parilisia) fausta (Al.) group in the fauna of Soviet Middle Asia // Vestnik Zoologii. No.4. P.3-8. [In Russian, with English summary].

Savchenko E.N. 1986. [The Limoniid-flies (general characteristic, subfamilies of pedicins and hexatomins)] // Fauna Ukrainy. Vol.14. Issue 2. Kiev: Naukova dumka. 380 p. [In Russian]. 